\title{
Sustainability Reporting dan Return Saham di Perusahaan Terindeks LQ45
}

\author{
Nyoman Weda ${ }^{1}$ \\ Fakultas Ekonomi dan Bisnis \\ Universitas Udayana, Indonesia
}

\author{
I Putu Sudana ${ }^{2}$ \\ Fakultas Ekonomi dan Bisnis \\ Universitas Udayana, Indonesia
}

\begin{abstract}
Surel : weda1507@gmail.com
ABSTRAK

Beberapa tahun terakhir, investor menekan perusahaan untuk mengungkapkan lebih banyak informasi keberlanjutan. Tujuan penelitian ini adalah untuk mengetahui pengaruh intensitas pengungkapan dalam sustainability reporting pada return saham. Penelitian ini dilakukan pada perusahaan dengan saham yang terdaftar dalam indeks LQ45 di BEI. Jumlah sampel yang diambil sebanyak 17 perusahaan, dengan metode purposive sampling. Pengumpulan data dilakukan dengan studi dokumentasi. Teknik analisis yang digunakan adalah teknik analisis regresi data panel. Hasil penelitian ditemukan bahwa intensitas pengungkapan dalam sustainability reporting tidak berpengaruh pada return saham. Intensitas pengungkapan yang tinggi belum tentu menarik minat investor untuk berinvestasi dan meningkatkan return saham perusahaan.
\end{abstract}

Kata Kunci: Sustainability Reporting; Profitabilitas; Ukuran Perusahaan; Return Saham.

\section{Sustainability Reporting and Stock Returns in LQ45 Indexed Companies}

\section{ABSTRACT}

In recent years, investors have put pressure on companies to disclose more sustainability information. The purpose of this study was to determine the effect of the intensity of disclosure in sustainability reporting on stock returns. This research was conducted on companies with shares listed in the LQ45 index on the IDX. The number of samples taken was 17 companies, with a purposive sampling method. Data collection was carried out by documentation study. The analysis technique used is the panel data regression analysis technique. The results showed that the intensity of disclosure in sustainability reporting has no effect on stock returns. The high intensity of disclosure does not necessarily attract investors to invest and increase the company's stock return.

Keywords: $\quad$ Sustainability Reporting; Profitability; Company Size; Stock Return.

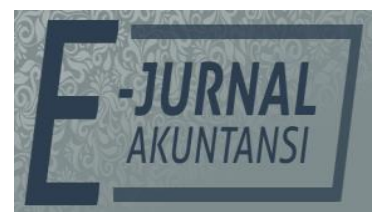

e-ISSN 2302-8556

Vol. 31 No. 6

Denpasar, Juni 2021

Hal. 1356-1374

DOI:

10.24843/EJA.2021.v31.i06.p01

PENGUTIPAN:

Weda, N. \& Sudana, I P.

(2021). Sustainability

Reporting dan Return Saham di Perusahaan Terindeks

LQ45. E-Jurnal Akuntansi,

31(6), 1356-1374

RIWAYAT ARTIKEL:

Artikel Masuk:

26 April 2021

Artikel Diterima:

10 Juni 2021

Artikel dapat diakses : https://ojs.unud.ac.id/index.php/Akuntansi/index 


\section{PENDAHULUAN}

Penelitian ini mengenai akuntansi keberlanjutan khususnya sustainability reporting (SR). Akuntansi keberlanjutan merupakan transformasi dari akuntansi konvensional dengan menerapkan konsep tanggung jawab sosial. Tanggung jawab sosial merupakan komitmen perusahaan untuk berkontribusi dalam pembangunan ekonomi yang berkelanjutan dengan menitikberatkan pada keseimbangan ekonomi, sosial dan lingkungan (Anggraini, 2015). Keseimbangan ekonomi, social, dan lingungan dikenal dengan istitah Triple Bottom Line atau profit, people, dan planet (3P) (Elkington, 1997). Hasil dari kegiatan akuntansi keberlanjutan berupa sustainability reporting yang berisikan informasi keberlanjutan perusahaan. Informasi keberlanjutan berkaitan dengan kinerja perusahaan yang berdampak pada ekonomi, social dan lingkungan di mana perusahaan beroperasi untuk mendukung pembangunan berkelanjutan (sustainable development.) Pembangunan berkelanjutan dilaksanankan guna memenuhi kebutuhan generasi saat ini tanpa mengurangi kemampuan generasi dimasa mendatang dalam memenuhi kebutuhannya (Brundtland, 1987).

Beberapa tahun terakhir, investor menekan perusahaan untuk mengungkapkan lebih banyak informasi keberlanjutan dan untuk meningkatkan kualitas pengungkapan mereka (Coulson \& O'Sullivan 2014) dan (Rinaldi et al., 2014). Investor mendorong informasi ini karena semakin banyak bukti yang menunjukkan bahwa perubahan iklim, penggundulan hutan, dan kerawanan air merupakan risiko bisnis bagi banyak perusahaan, dan berpotensi memengaruhi hasil investasi (Scott, 2020). Utama (2010) menyatakan sustainable development perlu diterapkan karena kegiatan ekonomi saat ini cenderung merusak ekosistem global dan menghambat kebutuhan generasi berikutnya. Dengan demikian, perlu adanya keterlibatan semua orang di seluruh dunia secara individu dan kolektif untuk tercapainya sustainable development (Sudana et al., 2014) Informasi terkait keberlanjutan menjadi penting sebagai transparansi dan akuntabilitas entitas guna mendukung pembangunan keberlanjutan. Investor kemudian mengajukan usulan pengungkapan informasi keberlanjutan.

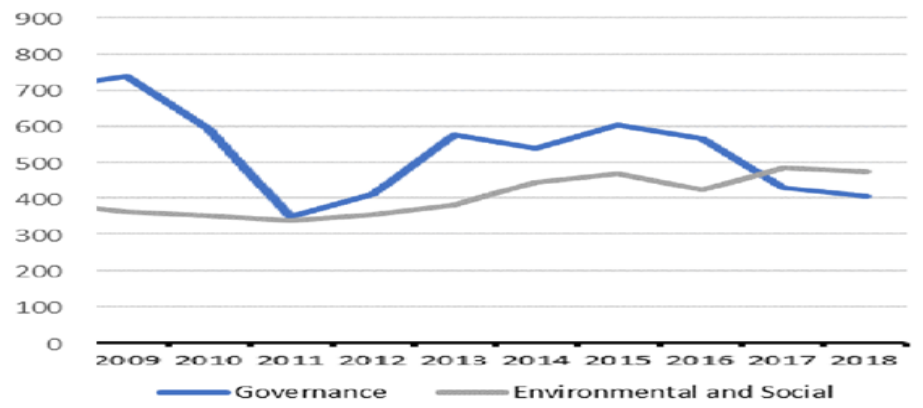

\section{Grafik 1. Usulan Pengungkapan Informasi Keberlanjutan kepada Perusahaan Tahun 2009-2018 di US}

Sumber: Papadopoulos (2019)

Survei yang dilakukan Papadopoulos (2019) di US sebagaimana disajikan pada Grafik 1, menunjukan bahwa adanya peningkatan usulan pengungkapan informasi keberlanjutan kepada perusahaan sejak tahun 2009 sampai tahun 2018. Survei yang dilakukan Norges Bank Investment Management (2020) juga menemukan adanya peningkatan usulan pengungkapan informasi keberlanjutan 
kepada perusahaan di US, Canada, Japan, dan belahan dunia lainnya. Di Indonesia, tuntutan untuk memberikan informasi keberlanjutan perusahaan tercermin dari dikeluarkannya regulasi oleh Otoritas Jasa Keuangan dalam POJK Nomor 51/POJK.03// 2017 tentang Penerapan Keuangan Berkelanjutan Kepada Lembaga Jasa Keuangan, Emiten dan Perusahaan Publik. Regulasi ini mewajibkan perusahaan untuk menerapkan keuangan berkelanjutan (pasal 2). Perusahaan dalam menerapkan keuangan berkelanjutan wajib menyusun Rencana aksi keuangan Berkelanjutan (pasal 4) dan Laporan keberlanjutan atau Sustainability reporting (pasal 10) (POJK Nomor 51/POJK.03/2017).

Menurut Prayosho \& Hananto (2013) sustainability reporting adalah media atau alat komunikasi untuk memberikan informasi mengenai apa saja yang dilakukan perusahaan kepada para pemangku kepentingan untuk mendukung pembangunan berkelanjutan. Elkington (1997) menyatakan sustainability reporting menyajikan tentang informasi kinerja keuangan (ekonomi) dan informasi kinerja non-keuangan (sosial dan lingkungan) perusahaan. Informasi dalam sustainability reporting mencerminkan tingkat aktivitas perusahaan secara keseluruhan untuk memungkinkan perusahaan untuk tumbuh terus menerus (kinerja berkelanjutan) (Nugroho \& Arjowo 2014). Dengan menerbitkan sustainability reporting maka dapat meningkatkan relevansi kinerja perusahaan secara berkelanjutan (Du et al., 2017). Melalui sustainability reporting pemangku kepentingan khususnya investor dapat mengetahui informasi bagaimana dana mereka dikelola tidak hanya pada aspek ekonomi melainkan juga pada aspek sosial dan lingkungan.

Perusahaan memiliki motivasi untuk melakukan pengungkapan sustainability reporting, hal ini dikarenakan adannya kontrak sosial yang terjadi antara perusahaan dengan masyarakat dimana perusahaan beroperasi. Sebagaimana dijelaskan Deegan (2004) mengenai teori legitimasi, bahwa manajemen berupaya memastikan kegiatan operasional perusahaan sebagai sesuatu yang sah yakni sesuai dengan norma yang ada dalam masyarakat. Vitola \& Rubino (2017) menjelaskan kontrak sosial didasarkan pada pertukaran yang saling menguntungkan. Apabila perusahaan mengungkap sustainability reporting maka keberadaaan dan aktivitas perusahaan akan diakui (terlegitimasi) oleh masyarakat bahwa perusahaan telah ikut andil dalam pembangunan keberlanjutan. Ketika perusahaan mengungkap informasi keberlanjutan dalam sustainability reporting untuk mendapatkan legitimasi, perusahaan tersebut sebenarnya juga memberikan sinyal bahwa perusahaan tersebut lebih baik dibandingkan perusahaan lainnya. Untuk mengurangi asimetri informasi tersebut maka perusahaan dapat memberikan sinyal.

Intensitas pengungkapan yang tinggi mengindikasikan bahwa perusahaan serius dalam mencapai tujuan berkelanjutan sehingga akan mampu menarik perhatian investor yang bersifat konservatif. Hal ini dikarenakan investor memiliki kecenderungan untuk melakukan investasi pada perusahaan yang transparan, artinya perusahaan tersebut memiliki informasi yang lengkap dan akurat sehingga dapat membantu investor dalam proses pengambilan keputusannya (Ernst \& Young, 2013). Investor tertarik akan informasi sosial yang dilaporkan perusahaan dalam laporan tahunan dan menganggap informasi ekonomi saja tak cukup sebagai pertimbangan berinvestasi (Epstein \& Freedman, 
1994). Sehingga investor akan tertarik untuk berinvestasi di perusahaan yang telah mampu menerbitkan sustainability reporting karena asimetri informasi semakin kecil (Nawawi et al., 2020).

Pemangku kepentingan khususnya investor yang akan melakukan investasi dengan membeli saham di pasar modal akan menganalisis kondisi perusahaan terlebih dahulu. Sebagaimana dijelaskan oleh Jogiyanto (2017:624), para pelaku pasar modal akan mengevaluasi setiap pengumuman yang diterbitkan perusahaan, demikian akan menyebabkan adanya perubahan pada transaksi perdagangan saham. Semakin besar apresiasi yang diberikan pasar terhadap perusahaan maka harga saham akan meningkat (Tanjung \& Wahyudi, 2019). Peningkatan harga saham menjadi harapan bagi semua investor karena harga saham yang tinggi akan berdampak bagi kemakmuran pemegang saham. Kenaikan atau penurunan harga saham akan berdampak pada kenaikan atau penurunan return saham (Karlina \& Widanaputra, 2016) dan (Antara \& Suryantini, 2019). Return dapat diartikan sebagai manfaat masa depan atau tingkat pengembalian yang akan diterima oleh investor atas investasi yang dilakukannya. Return yang diterima pemangku kepentingan atas kepemilikan perusahaan dinamakan return saham.

Penelitian Reddy \& Gordon (2010) di Australia mengungkapkan perusahaan dengan tingkat pelaporan keberlanjutan yang tinggi cenderung memiliki tingkat return saham yang tinggi pula. Penelitian Ansari et al. (2015) pada perusahaan real estate di Eropa, Amerika Serikat, dan Australia menujukan bahwa sustainability reporting memiliki pengaruh pada return saham yang diproyeksikan dengan abnormal return. Penelitian Glamedita (2017) pada perusahaan non keuangan di bursa efek Indonesia menunjukan bahwa terdapat kecenderungan perusahaan yang memiliki tingkat pengungkapan sustainability reporting yang tinggi maka akan diperoleh return yang tinggi dan sebaliknya. Santi (2014) juga menemukan bahwa sustainability reporting berpengaruh positif pada return saham. Berbeda dengan penelitian Prayosho \& Hananto (2013), Wijaya \& Sudana (2017), Aji \& Juliarto (2018), dan Nawawi et al., (2020) yang menyatakan sustainability reporting tidak berpengaruh pada return saham. Kemungkinan besar hal ini terjadi karena investor di pasar modal indonesia belum memahami pentingnya mengelola perusahaan secara berkelanjutan.

Pemangku kepentingan khususnya investor dalam menganalisis kondisi perusahaan tentu menggunakan berbagai informasi sebagai pertimbangan dalam pengambilan keputusan. Salah satu informasi yang juga digunakan sebagai pertimbangan yakni kinerja keuangan perusahaan. Kinerja keuangan perusahaan merupakan informasi akuntansi yang berperan mendorong keyakinan investor dalam mengambil keputusan investasi (Beaver, 1970). Berdasarkan pernyataan tersebut maka dalam penelitian ini, kinerja keuangan perusahaan dilibatkan sebagai variabel kontrol. Penyertaan variabel kontrol kedalam model penelitian akan menghasilkan analisis yang lebih baik. Hal ini dikarenakan variabel lain yang secara teori berpengaruh pada variabel dependen disertakan ke dalam model penelitian, demikian hasil dari penelitian akan mempunyai statistic power yang lebih tinggi (Widhiarso, 2011). Penelitian ini melibatkan kinerja keuangan yakni profitabilitas yang diproksikan dengan return on equity dan ukuran perusahaan yang diproksikan dengan total asset. 
Meningkatnya kebutuhan pengungkapan informasi keberlanjutan kepada perusahaan untuk mendukung investasi yang bertanggung jawab serta tidak konsistenya antar temuan terdahulu menyebabkan informasi mengenai pengaruh sustainability reporting pada return saham masih belum jelas. Sehingga peneliti mencoba melakukan penelitian dengan tujuan menunjukan pengaruh sustainability reporting pada return saham setelah diberlakukannya regulasi pengungkapan sustainability reporting. Penelitian ini penting dilakukan untuk mengetahui bagaimana pengaruh dari sustainability reporting pada return saham untuk mendukung investasi yang bertanggung jawab agar memberikan dampak positif terhadap investor maupun sosial dan lingkungan tempat perusahaan beroperasi.

Penelitian terdahulu cenderung berfokus pada masing-masing sektor industri oleh karena itu penelitian ini dilakukan pada perusahaan yang tergabung kedalam indeks LQ45 yang terdaftar pada Bursa Efek Indonesia. Perusahaan yang tergabung kedalam indeks LQ45 merupakan perusahaan yang memiliki tingkat likuiditas yang tinggi dan kapitalisasi pasar besar serta didukung oleh fundamental perusahaan yang baik (Indonesia Stock Exchange, 2020). Oleh karena itu sudah sepatutnya perusahaan yang tergabung kedalam indeks LQ45 menyampaikan informasi yang bermanfaat bagi investor. Berdasarkan fenomena dan uraian latar belakang yang telah disampaikan maka peneliti tertarik melakukan penelitian dengan judul "Sustainability reporting dan Return Saham Pada Perusahaan Terindeks LQ45".

Kajian penelitian terdahulu yang mendukung hubungan pengaruh sustainability reporting pada return saham yakni penelitian Reddy \& Gordon (2010), Ansari et al. (2015), Glamedita (2017) dan Santi (2014) yang menemukan bahwa sustainability reporting berpengaruh positif pada return saham. Berdasarkan pemaparan teori dan kajian penelitian terdahulu maka hipotesis yang diajukan adalah sebagai berikut.

$\mathrm{H}_{1}$ : Intensitas pengungkapan dalam sustainability reporting berpengaruh positif pada return saham.

\section{METODE PENELITIAN}

Untuk mengetahui pengaruh positif intensitas pengungkapan dalam sustainability reporting pada return saham, pada penelitian ini digunakan metode asosiatif dengan pendekatan kuantitatif. Penelitian ini dilakukan pada perusahaan dengan saham yang terdaftar dalam indeks LQ45 di BEI. Penelitian ini menggunakan satu variabel terikat yakni return saham dan satu variabel bebas yakni sustainability reporting yang diproksikan dengan sustainability report disclosure index (SRDI). Pada penelitian ini disertakan juga variabel kontrol yakni profitabilitas yang diproksikan dengan return on equity dan ukuran perusahaan yang diproksikan dengan total asset perusahaan. Return saham diukur selama 6 bulan setelah pungungkapan sustainability report oleh perusahaan. Return saham dapat dihitung dengan rumus sebagai berikut.

$R_{t}=\frac{P_{t}-P_{t-1}}{P_{t-1}}$ 
Sustainability Report Disclosure Index (SRDI) merupakan suatu index yang digunakan untuk menilai bagaimana tanggung jawab perusahaan sesuai dengan kriteria menurut GRI. Kriteria pelaporan yang akan digunakan disesuaikan dengan pernyataan pelaporan oleh perusahaan yaitu kriteria pelaporan inti atau kriteria pelaporan komprehensif berdasarkan GRI G4 dan GRI Standar. Perusahaan yang memilih opsi inti diwajibkan menyampaikan minimal satu indikator dari aspek material, sedangkan untuk opsi komprehensif wajib menyampaikan semua indikator dari aspek material yang telah diidentifikasi organisasi (Global Reporting Initiative, 2013:12).

Pada penelitian ini hanya menggunakan pengungkapan standar khusus untuk perhitungan SRDI karena penjelasan mengenai dampak signifikan pada aspek ekonomi, sosial, dan lingkungan pada pengungkapan standar khusus dapat digunakan oleh pemangku kepentingan untuk menilai kinerja dan prospek perusahaan kedepanya. Perhitungan SRDI dilakukan dengan memberikan skor 1 jika item diungkapkan, dan 0 jika tidak diungkapkan. Setelah dilakukan penilaian pada semua item, skor tersebut kemudian dijumlahkan untuk mendapatkan skor keseluruhan untuk masing-masing perusahaan. Berikut adalah perhitungan yang dapat digunakan untuk memperoleh SRDI (Natalia \& Tarigan 2014).

$$
\mathrm{SRDI}=\frac{\mathrm{n}}{\mathrm{k}}
$$

Return on equity merupakan alat untuk mengukur seberapa kuat perusahaan untuk menghasilkan keuntungan yang menjadi hak pemegang sahamnya (Husnan \& Pudjiastuti, 2015). Jika tingkat return on equity tinggi maka pemegang sahamnya juga akan mendapatkan keuntungan yang tinggi pula, namun jika perusahaan mengalami kerugian maka pemegang saham juga akan menanggung kerugian tersebut (Adiatma \& Suryanawa, 2018). Menurut Brigham \& Houston (2011), Return on equity dapat dirumuskan sebagai berikut.

$$
\mathrm{ROE}=\frac{\text { EAT }}{\text { Total Ekuitas }}
$$

Ukuran perusahaan merupakan gambaran kemampuan finansial perusahaan dalam satu periode tertentu (Joni \& Lina, 2010). Handayani et al. (2019) menyatakan bahwa semakin besar perusahaan maka semakin tinggi tingkat kepercayaan yang diberikan investor dalam menanamkan investasinya kepada perusahaan tersebut. Menurut Yuliantarai \& Sujana (2014), ukuran perusahaan diperoleh dengan melogaritmakan nilai total asset dari perusahaan bersangkutan. Dengan menggunakan natural log, nilai tersebut dapat disederhanakan tanpa mengubah proporsi nilai asal yang sebenarnya (Kholisah, 2013). Berdasarkan hal tersebut, size atau ukuran perusahaan dapat dirumuskan sebagai berikut.

Size $=$ Ln $($ Total Aset $)$

Populasi dalam penelitian ini adalah perusahaan yang terdaftar dalam indeks LQ 45 di BEI periode 2017-2019. Sampel dipilih sebanyak 34 perusahaan. Teknik pengambilan sampel dilakukan dengan purposive sampling method. 
Purposive sampling method merupakan sebuah teknik pengambilan sampel atas suatu populasi berdasarkan kriteria atau pertimbangan tertentu.

Tabel 1. Kriteria Pemilihan Sampel

\begin{tabular}{llc}
\hline No & \multicolumn{1}{c}{ Kriteria } & Perusahaan \\
\hline 1 & $\begin{array}{l}\text { Perusahaan yang terdaftar di BEI dan tetap tercatat } \\
\text { pada index LQ 45 periode 2017 sampai dengan 2019 }\end{array}$ & 33 \\
2 & $\begin{array}{l}\text { Perusahaan yang mempublikasikan sustainability } \\
\text { reporting secara lengkap periode 2017 sampai dengan }\end{array}$ & 17 \\
$2018 \quad$ Sampel yang digunakan sebanyak 17 Perusahaan
\end{tabular}

Sumber: Data Penelitian, 2020

Metode pengumpulan data yakni studi dokumentasi. Data yang digunakan dalam penelitian ini adalah data kuantitatif dari sumber sekunder. Data kuantitatif yang digunakan dalam penelitian ini adalah sustainability reporting, kinerja keuangan, dan kinerja saham perusahaan LQ 45. Sumber sekunder yakni sustainability reporting dan laporan tahunan tahun 2017-2018 pada perusahaan LQ45 yang diunduh dari situs resmi BEI (www.idx.co.id) dan web masingmasing perusahaan, kemudian kinerja saham tahun 2018-2019 diunduh dari situs yahoo finance. Alasan penggunaan data sustainability reporting dan laporan tahunan tahun 2017-2018 dikarenakan ketersediaan data dan sustainability reporting bersifat wajib mulai tahun 2017 sedangkan tahun sebelumnya hanya bersifat sukarela. Alasan penggunaan data kinerja saham tahun 2018-2019 dikarenakan ketersedian data.

Teknik analisis data yang digunakan adalah analisis statistik deskriptif, uji asumsi klasik, analisis regresi data panel, uji kelayakan model, dan uji parsial dengan bantuan aplikasi Eviews 9. Estimasi model regresi data panel dalam penelitian ini menggunakan common effect model (pooled least square) yaitu menggabungkan seluruh data time series dengan cross section, selanjutnya dilakukan analisis regresi dengan menggunakan OLS (Ordinary Least Square). Parameter diasumsikan sama untuk semua individu. Model Common Effect dapat diformulasikan sebagai berikut.

Keterangan:

$$
\mathrm{y}_{\mathrm{it}}=a+\beta_{1} x_{1 i t}+\beta_{2} x_{2 i t}+\beta_{3} x_{3 i t}+\varepsilon_{i t}
$$

$$
\begin{aligned}
& \mathrm{Y}=\text { Return Saham } \\
& \alpha=\text { intersep } \\
& \beta=\text { parameter } \\
& x_{1}=\text { Sustainability reporting disclosure index (SRDI) } \\
& x_{2}=\text { Return on Equity } \\
& x_{3}=\text { Ln total asset } \\
& \varepsilon=\text { komponen } \text { error } \\
& \mathrm{i}=\text { urutan perusahan yang diobservasi (cross section) } \\
& \mathrm{t}=\text { periode waktu (time series) }
\end{aligned}
$$

\section{HASIL DAN PEMBAHASAN}

Sebelum pengujian hipotesis, diuraikan mengenai deskripsi sampel dan deskripsi variabel-variabel penelitian, baik variabel dependen maupun 
independen. Analisis statistik deskriptif yang dilakukan dalam penelitian bertujuan untuk mengetahui gambaran atau penyebaran data sampel.

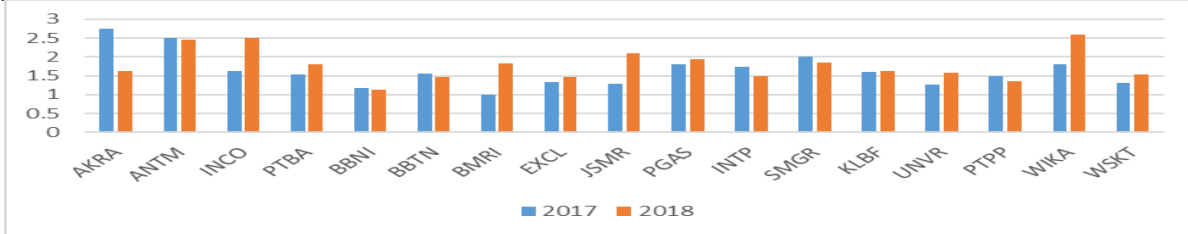

Grafik 2. SRDI Perusahaan Terindeks LQ45 Tahun 2017-2018

Sumber: Data Penelitian, 2020

Pada Grafik 2, dapat diketahui intensitas pengungkapan (SRDI) oleh perusahaan yang tergabung dalam indeks LQ45 cenderung mengalami peningkatan pada tahun 2018 dibandingkan dengan tahun 2017. Perusahaan yang memiliki nilai SRDI tertinggi pada tahun 2017 bergerak pada sektor perdagangan dan investasi dengan kode emiten AKRA yakni sebesar 2,75 dan perusahaan dengan nilai tertinggi pada tahun 2018 bergerak pada sektor properti, perumahan, dan kontruksi bangunan dengan kode emiten WIKA yakni 2,6. Nilai SRDI lebih tinggi dari 1 hal ini berarti indikator pengungkapan oleh perusahaan lebih tinggi dari indikator harapan berdasarkan opsi pelaporan yang dipilih. Sedangkan perusahaan yang memiliki nilai SRDI terendah pada tahun 2017 bergerak pada sektor keuangan dengan kode emiten BMRI yakni sebesar 1 . Untuk tahun 2018 semua perusahaan memiliki nilai SRDI lebih tinggi dari 1.

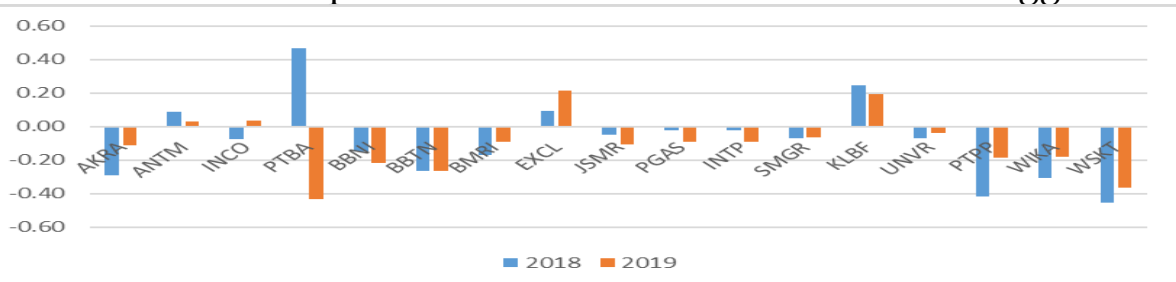

\section{Grafik 3. Total Return Saham Perusahaan Terindeks LQ45 Selama 6 Bulan (Periode Tahun 2018 dan 2019)}

Sumber: Data Penelitian, 2020

Pada Grafik 3, dapat diketahui tingkat return saham tertinggi pada tahun 2018 dimiliki oleh emiten dengan kode PTBA yang bergerak pada sektor pertambangan, memiliki nilai return 0,46 atau positif 46 persen. Nilai return positif berarti investor mendapatkan capital gain sebesar 0,46 atau positif 46 persen dari nilai investasi awal. Kemudian tahun 2018 return terendah dimiliki oleh emiten dengan kode WSKT yang bergerak pada sektor properti, perumahan, dan kontruksi bangunan, memiliki nilai return $-0,45$ atau negatif 45 persen. Nilai return negatif berarti investor mendapatkan capital loss $-0,45$ atau negatif 45 persen persen dari nilai investasi awal. Sedangkan pada tahun 2019 return tertinggi dimiliki oleh emiten dengan kode EXCL yang bergerak pada sektor infrastruktur, utilitas, dan transportasi, memiliki nilai return 0,21 atau positif 21 persen. Kemudian tahun 2019 return terendah dimiliki oleh emiten dengan kode PTBA yang bergerak pada sektor pertambangan, memiliki nilai return $-0,43$ atau negatif 43 persen.

Pada Grafik 4, dapat diketahui jumlah indikator pengungkapan bidang ekonomi oleh perusahaan yang tergabung dalam indeks LQ45. Pada tahun 2017 sampai 2018 fokus pengungkapan pada bidang ekonomi yakni mengenai kinerja 
ekonomi, dampak ekonomi tidak langsung, dan anti-korupsi. Indikator-indikator tersebut merupakan indikator yang paling banyak diungkap dalam sustainability reporting dan diduga memiliki pengaruh pada return saham perusahaan.

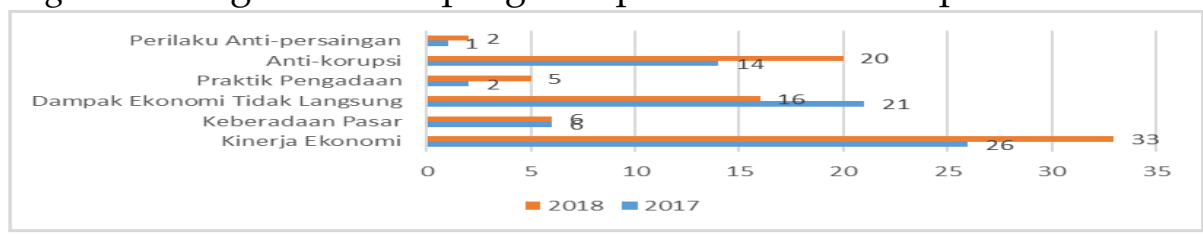

\section{Grafik 4. Jumlah Item Pengungkapan Bidang Ekonomi Perusahaan Terindeks} LQ45 Tahun 2017-2018

Sumber: Data Penelitian, 2020

Pada Grafik 5, dapat diketahui jumlah indikator pengungkapan bidang lingkungan oleh perusahaan yang tergabung dalam indeks LQ45. Pada tahun 2017 sampai 2018 fokus pengungkapan pada bidang lingkungan yakni mengenai energi, emisi, dan air limbah (efluen) \& limbah. Indikator-indikator tersebut merupakan indikator yang paling banyak diungkap dalam sustainability reporting dan diduga memiliki pengaruh pada return saham perusahaan.

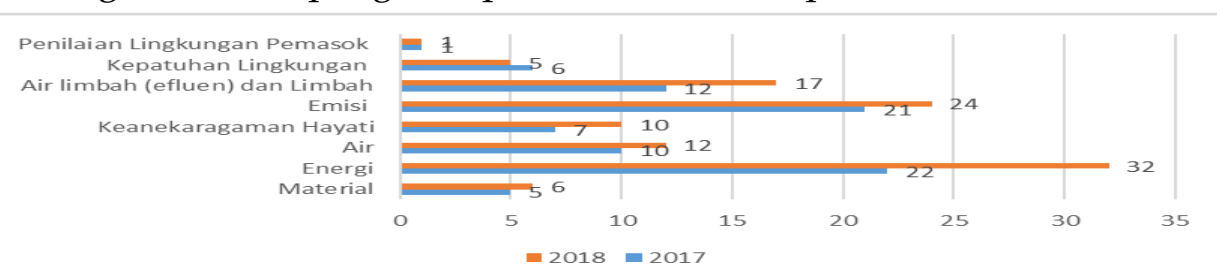

Grafik 5. Jumlah Item Pengungkapan Bidang Lingkungan Perusahaan Terindeks LQ45 Tahun 2017-2018

Sumber: Data Penelitian, 2020

Pada Grafik 6, dapat diketahui jumlah indikator pengungkapan bidang sosial oleh perusahaan yang tergabung dalam indeks LQ45. Pada tahun 2017 sampai 2018 fokus pengungkapan pada bidang sosial yakni mengenai kepegawaian, kesehatan dan keselamatan kerja (K3), dan pelatihan \& pendidikan. Indikator-indikator tersebut merupakan indikator yang paling banyak diungkap dalam sustainability reporting dan diduga memiliki pengaruh pada return saham perusahaan.

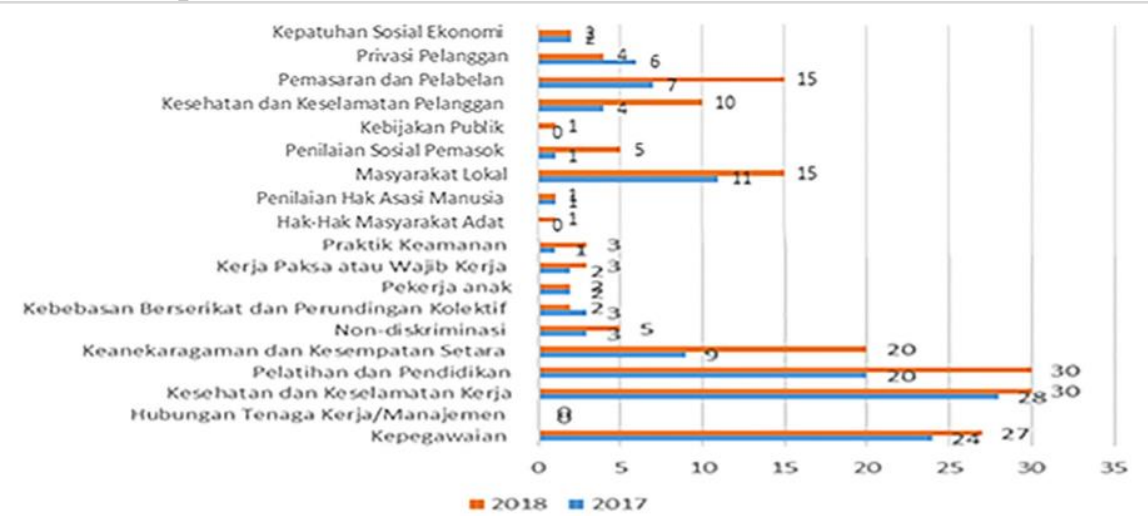

\section{Grafik 6. Jumlah Item Pengungkapan Bidang Sosial Perusahaan Terindeks} LQ45 Tahun 2017-2018

Sumber: Data Penelitian, 2020 
Hasil statistik deskriptif data sebagai berikut, nilai minimum dari return saham adalah sebesar -0,452941 yang merupakan nilai dari PT. Waskita Karya (Persero) Tbk pada kurun tahun 2018 yang bergerak pada sektor Properti, Perumahan dan Konstruksi bangunan. Nilai maksimum return saham adalah sebesar 0,469388 yang merupakan nilai dari PT. Tambang Batubara Bukit Asam (Persero) Tbk pada kurun tahun 2018 yang bergerak pada pertambangan. Nilai rata-rata sebesar $-0,094743$ dengan standar deviasi 0,200995. Nilai rata-rata sebesar -0,094743 lebih kecil dari nilai standar deviasi yaitu 0,200995 menandakan ada fluktuasi tinggi pada data return saham perusahaan yang menjadi sampel.

Nilai minimum dari SRDI adalah sebesar 1 yang merupakan nilai dari PT. Bank Mandiri (Persero) Tbk pada tahun 2017 yang bergerak pada sektor keuangan. Nilai maksimum SRDI adalah sebesar 2,75 yang merupakan nilai dari PT. AKR Corporindo Tbk pada tahun 2017 yang bergerak pada sektor perdagangan dan investasi. Nilai rata-rata SRDI sebesar 1,690384 dengan standar deviasi 0,393509. Nilai rata-rata sebesar 0,5648 lebih besar dari nilai standar deviasi yaitu 0,29608 menandakan bahwa ada fluktuasi rendah pada data SRDI perusahaan yang menjadi sampel.

Nilai minimum dari ROE adalah sebesar $-0,180000$ yang merupakan nilai dari PT. XL Axiata Tbk pada kurun tahun 2018 yang bergerak pada sektor Infrastruktur, utilitas \& transportasi. Nilai maksimum ROE adalah sebesar 1,446000 yang merupakan nilai dari PT. Unilever Indonesia Tbk pada kurun tahun 2018 yang bergerak pada sektor Industri Barang Konsumsi. Nilai rata-rata sebesar 0,192521 dengan standar deviasi 0,327512. Nilai rata-rata sebesar 0,192521 lebih kecil dari nilai standar deviasi yaitu 0,327512 menandakan bahwa artinya ada fluktuasi tinggi pada ROE saham perusahaan yang menjadi sampel.

Nilai minimum dari ukuran perusahaan adalah sebesar 30,44140 yang merupakan nilai dari PT. Kalbe Farma Tbk pada kurun tahun 2017 yang bergerak pada sektor barang konsumsi. Nilai maksimum ukuran perusahaan adalah sebesar 37,05963 yang merupakan nilai dari PT. Waskita Karya (Persero) Tbk pada kurun tahun 2018 yang bergerak pada sektor Properti, Perumahan dan Konstruksi bangunan. Nilai rata-rata sebesar 32,00905 dengan standar deviasi 1,699670. Nilai rata-rata sebesar 32,00905 lebih besar dari nilai standar deviasi yaitu 1,699670 menandakan bahwa artinya ada fluktuasi rendah pada ukuran perusahaan yang menjadi sampel.

Tabel 2. Hasil Uji Normalitas (Jarque-Bera)

\begin{tabular}{ll}
\hline $\mathrm{N}$ & 34 \\
\hline t-statistic & 1,455847 \\
Probability & 0,482911
\end{tabular}

Sumber: Data Penelitian, 2021

Berdasarkan hasil uji normalitas dapat diketahui bahwa nilai probabilitas yang dihasilkan untuk persamaan regresi dari return saham adalah sebesar 0,482911, nilai tersebut yaitu 0,482911> level of significant (0.05). Berdasarkan hal tersebut disimpulkan bahwa variabel pada persamaan return saham yang digunakan pada penelitian ini sudah berdistribusi normal. 
Tabel 3. Hasil Uji Heteroskedatisitas (Glejser)

\begin{tabular}{ccccc}
\hline Variabel & Koefisien & Standar Error & t-Statistic & $\begin{array}{c}\text { Nilai } \\
\text { Probabilitas }\end{array}$ \\
\hline C & 0,963302 & 0,475261 & 2,026889 & 0,0516 \\
SRDI & $-0,028195$ & 0,057987 & $-0,486242$ & 0,6303 \\
ROE & 0,053696 & 0,066756 & 0,804364 & 0,4275 \\
SIZE & $-0,024373$ & 0,013294 & $-1,833386$ & 0,0767 \\
\hline
\end{tabular}

Sumber: Data Penelitian, 2021

Berdasarkan hasil uji heteroskedastitas dapat diketahui bahwa nilai SRDI sebesar 0,6303, ROE sebesar 0,4275, dan SIZE sebear 0,0767. Nilai yang dihasilkan lebih besar dari 0,05 sehingga dapat disimpulkan data bebas dari heteroskedastisitas.

Tabel 4. Hasil Uji Multikolinearitas

\begin{tabular}{ccrc}
\hline & $X_{1}$ & \multicolumn{1}{c}{$X_{2}$} & $X_{3}$ \\
\hline$X_{1}$ & 1,000000 & $-0,212574$ & $-0,325652$ \\
$X_{2}$ & $-0,212574$ & 1,000000 & $-0,162081$ \\
$X_{3}$ & $-0,325652$ & $-0,162081$ & 1,000000 \\
\hline
\end{tabular}

Sumber: Data Penelitian, 2021

Keterangan: $\mathrm{X}_{1}=S R D I, \mathrm{X}_{2}=R O E, \mathrm{X}_{3}=S I Z E$

Berdasarkan hasil uji multikolinearitas dapat diketahui bahwa tidak terdapat nilai korelasi yang melebihi 0,80 , sehingga disimpulkan tidak terdapat multikolinearitas antar variabel bebas.

Tabel 5. Hasil Common Effect Model (Pooled Least Square)

\begin{tabular}{lrrrrc}
\hline \multicolumn{2}{c}{ Variabel Independen } & \multicolumn{2}{c}{ Nilai Koefisien } & Nilai $t$-Statistic & Nilai Probabilitas \\
\hline \multicolumn{2}{c}{ Konstanta } & $\mathrm{a}$ & 2,033444 & & \\
SRDI $\left(\mathrm{X}_{1}\right)$ & & $\beta_{1}$ & $-0,058158$ & $-0,650610$ & 0,5203 \\
$\operatorname{ROE}\left(\mathrm{X}_{2}\right)$ & & $\beta_{2}$ & 0,084350 & 0,819656 & 0,4189 \\
$\operatorname{SIZE}\left(\mathrm{X}_{3}\right)$ & & $\beta_{3}$ & $-0,062908$ & $-3,069643$ & 0,0045 \\
R-squared & 0,245043 & & & & \\
Adjusted -squared & 0,169548 & & & & \\
F-statistic & 3,245792 & & & & \\
Prob(F-statistic) & 0,035619 & & & \\
\hline
\end{tabular}

Sumber: Data Penelitian, 2021

Berdasarkan Tabel 5, dapat diketahui nilai konstanta (a) benilai sebesar 2,033444 maka dapat diartikan apabila tidak terdapat pengaruh dari variabel lain atau variabel bebas, maka nilai dari variabel return saham adalah sebesar 2,033444 satuan. Nilai koefisien ( $\beta 3$ ) variabel ukuran perusahaan bernilai 0,062908 artinya apabila terjadi kenaikan ukuran perusahaan yang diproksikan dengan total asset sebanyak 1 satuan maka return saham mengalami penurunan sebesar $-0,062908$ satuan.

Berdasarkan Tabel 5, diketahui nilai Nilai Adjusted R-squared adalah sebesar 0,169548 menunjukkan bahwa keragaman variabel return saham dapat dijelaskan sebesar 16,95 persen oleh intensitas pengungkapan sustainability reporting, profitabilitas, dan ukuran perusahaan. Sebesar 80,05 persen dijelaskan oleh variabel yang tidak diteliti dalam penelitian ini. Hasil dari uji kelayakan model menunjukan modal yang digunakan mampu menjelaskan return saham. Berdasarkan Tabel 4.5 diketahui pada model regresi diperoleh nilai signifikansi sebesar 0,035619. Karena nilai signifikansi lebih kecil dari 0,05 berarti model 
yang digunakan dalam penelitian ini adalah layak. Kelayakan model ini mencerminkan return saham dapat dijelaskan dengan variabel sustainability reporting, profitabilitas, dan ukuran perusahaan.

Berdasarkan Tabel 5, diketahui nilai koefisien regresi intensitas pengungkapan dalam sustainability reporting yakni sebesar -0.058158 dengan nilai signifikansi sebesar 0,5203. Nilai signifikansi 0,5203 lebih besar dari nilai $\alpha=$ 0,05 demikian intensitas pengungkapan dalam sustainability reporting tidak berpengaruh pada return saham. Hipotesis yang menyatakan intensitas pengungkapan dalam sustainability reporting berpengaruh positif pada return saham tidak diterima. Berdasarkan Tabel 5, diketahui nilai koefisien profitabilitas yang diproksikan dengan return on equity yakni sebesar 0.084350 dengan nilai signifikansi sebesar 0,4189. Nilai signifikansi 0,4189 lebih besar dari nilai $\alpha=0,05$. Sehingga return on equity (ROE) tidak berpengaruh pada return saham. Berdasarkan Tabel 5, diketahui nilai koefisien ukuran perusahaan yang diproksikan dengan Ln total asset yakni sebesar -0,062908 dengan nilai signifikansi sebesar 0,0045. Nilai signifikansi 0,0045 lebih kecil dari nilai $a=0,05$. Sehingga ukuran perusahaan berpengaruh pada return saham dengan arah negatif.

Pengaruh intensitas pengungkapan dalam sustainability reporting pada return saham. Berdasarkan hasil analisis regresi data panel pada Tabel 5, serta pengujian hipotesis, diketahui bahwa hipotesis dalam penelitian ini tidak diterima. Temuan dalam penelitian ini yakni intensitas pengungkapan dalam sustainability reporting tidak berpengaruh pada return saham. Hasil dari penelitian ini bertentangan dengan hasil penelitian yang dilakukan oleh Reddy \& Gordon (2010), Santi (2014), Ansari et al. (2015), dan Glamedita (2017) yang menyatakan bahwa sustainability reporting berpengaruh positif pada return saham. Hasil penelitian ini sejalan dengan hasil penelitian Prayosho \& Hananto (2013), Wijaya \& Sudana (2017), dan Nawawi et al. (2020) yang menyatakan sustainability reporting tidak berpengaruh pada return saham.

Nawawi et al., (2020) menjelaskan pengungkapan SR tidak berpengaruh pada kinerja saham, karena investor masih tidak mempertimbangkan pelaporan keberlanjutan serta harga saham spekulatif berpengaruh terhadap penilaian calon investor. Stekelenburg et al., (2015) menjelaskan pengungkapan SR tidak berpengaruh terhadap kinerja saham karena perusahaan yang menerbitkan SR masih belum menyampaikan informasi secara maksimal atau masih kurang terbuka. Pada penelitian ini pengungkapan yang dilakukan perusahaan masih kurang terbuka, hanya berfokus pada beberapa aspek pengungkapan saja (Grafik 4.3-4.5) dan pengungkapan tersebut cenderung hanya memperlihatkan dampak positif aktivitas perusahaan, sulit untuk melihat kebenaran dari pengungkapan informasi tersebut. Informasi keberlanjutan diungkap hanya setiap akhir tahun pelaporan. Namun informasi mengenai progresnya sulit untuk diketahui, faktanya kesenjangan sosial dan masih banyak kerusakaan lingkungan yang terjadi di Indonesia.

Teori legitimasi menegaskan bahwa perusahaan terus berupaya untuk memastikan kegiatan operasional perusahaan sesuai dalam bingkai dan norma yang ada dalam masyarakat atau lingkungan dimana perusahaan berada (Deegan, 2004). Tarigan \& Semuel (2014) menjelaskan legitimasi dari masyarakat 
penting bagi perusahaan karena legitimasi merupakan sumber daya operasional yang berhubungan dengan going concern perusahaan. Ketika perusahaan berada di bawah tekanan untuk mematuhi peraturan, manajer perusahaan dapat menyembunyikan proyek yang menguntungkan tetapi merugikan lingkungan (Tang \& Zhong, 2019). Demikian pengungkapan yang belum maksimal atau masih kurang terbuka yang dilakukan perusahaan adalah upaya untuk memenuhi tuntutan dari masyarakat atau untuk mendapatkan legitimasi bukan untuk perbaikan dalam mendorong pembangunan keberlanjutan. Sebagaimana dijelaskan Ernst \& Young (2013) yang transparan, artinya perusahaan tersebut memiliki informasi yang lengkap dan akurat sehingga dapat membantu investor dalam proses pengambilan keputusannya. Pengungkapan untuk mendapatkan legitimasi ini tidak membuat investor tetarik untuk menggunakan sustainability reporting dalam pertimbangan pengambilan keputusan sehingga tidak mempengaruhi return saham perusahaan.

Selain pengungkapan diyakini hanya untuk legitimasi, investor juga belum sadar akan pentingnya mengelola perusahaan secara keberlanjutan. Sebagaimana dijelaskan Prayoso \& Hananto (2013) dan Ismaeel \& Zakaria (2019) Tidak semua investor di pasar modal indonesia memiliki pemahaman yang memadai mengenai sustainability reporting. Demikian ketidakpahaman ini berarti investor tidak menggunakan sustainability reporting sebagai pertimbangan dalam membuat keputusan. Kemungkinan hanya investor institusi yang menggunakan informasi keberlanjutan karena investasi yang dilakukan cenderung jangka panjang sehingga diperlukan berbagai informasi dan analisa mendalam akan informasi tersebut. Hal ini diperkuat dengan laporan EY's Tomorrow's investment rules tahun 2017, yang melibatkan lebih dari 320 investor institusi di seluruh dunia, hampir $86 \%$ responden menyatakan laporan keberlanjutan sebagai hal yang penting saat membuat keputusan investasi (Nelson, 2017).

Pengaruh profitabilitas pada return saham. Berdasarkan Tabel 5, Nilai signifikansi profitabilitas yang diproksikan dengan return on equity yakni 0,4189 lebih besar dari nilai $a=0,05$. Return on equity (ROE) tidak berpengaruh pada return saham. Hal ini berarti bahwa return on equity sebagai informasi yang menunjukan kemampuan perusahaan untuk menghasilkan keuntungan bagi pemegang sahamnya tidak digunakan sebagai pertimbangan dalam membuat keputusan investasi oleh investor. Hasil ini tidak sesuai dengan teori sinyal yang mengindikasikan dengan adanya return on equity, menunjukan kesuksesan manajemen dalam memaksimalkan tingkat pengembalian pada pemegang saham. Informasi peningkatan return on equity akan diterima pasar sebagai sinyal baik yang akan memberikan masukan positif bagi investor. Perusahaan yang memiliki return on equity tinggi akan menghasilkan laba yang tinggi pula, sehingga akan berpengaruh positif terhadap return saham (Sailendra \& Suratno, 2014).

Ketika return on equity meningkat tidak menjamin memiliki return saham yang tinggi pula. Hal ini terjadi karena return on equity hanya menggambarkan besarnya pengembalian atas investasi yang dilakukan pemegang saham biasa, namun tidak menggambarkan prospek perusahaan sehingga pasar tidak terlalu merespon dengan besar kecilnya return on equity sebagai pertimbangan investasi yang akan dilakukan investor. Hasil penelitian ini sejalan dengan Sasongko 
(2006), Sudiyatno \& Suharmanto (2011), dan Tjahjono (2017) menyatakan bahwa return on equity tidak berpengaruh pada return saham. Namun bertentangan dengan Har \& Ghafar (2015), Candradewi (2016), dan Wirasedana \& Setiawan (2020) yang mengungkapkan return on equity berpengaruh positif pada return saham.

Pengaruh ukuran perusahaan pada return saham. Berdasarkan Tabel 5, Nilai signifikansi ukuran perusahaan yang diproksikan dengan Ln total asset yakni 0,0045 lebih kecil dari nilai a =0,05. Ukuran perusahaan berpengaruh pada return saham dengan arah negatif. Hal ini berarti ukuran perusahaan yang merupakan gambaran kemampuan finansial perusahaan dalam satu periode tertentu direspon sebagai sinyal negatif. Hasil ini sesuai dengan teori sinyal yang menekankan kepada pentingnya informasi yang dikeluarkan oleh perusahaan terhadap keputusan investasi pihak luar perusahaan. Informasi mengenai perusahaan merupakan sinyal bagi investor dalam keputusan berinvestasi (Brigham \& Houston, 2011:76). Pada periode penelitian ini ukuran perusahaan yang semakin tinggi dapat menurunkan return saham perusahaan.

Hal ini dijelaskan dengan fenomena size effect dimana ada kecenderungan ukuran perusahaan yang lebih kecil dapat memiliki return saham yang lebih tinggi dibandingkan dengan ukuran perusahaan yang lebih besar dan sebaliknya (Har \& Rashid, 2014). Namun kecenderungan ini tidak umum untuk semua periode waktu dan di semua pasar modal (Dimson \& Marsh, 1999) dan (AlRojoub et al., 2005). Selain itu data return saham dalam periode penelitian ini cenderungan turun saat ukuran perusahaan yang diproksikan dengan total asset meningkat, tentu hal ini dapat menyebabkan pengaruh signifikan ukuran perusahaan menjadi negatif. Demikian hasil penelitian ini sejalan dengan Mills \& Jordanov (2003) dan Haq \& Rashid (2014) yang mengungkapakan ukuran perusahaan berpengaruh negatif pada return saham. Temuan ini bertetantangan dengan Sudarsono \& Sudiyatno (2016), Putra \& Dana (2016), Acheampong et al. (2014), dan Handayani et al. (2019) yang mengungkapkan ukuran perusahaan berpengaruh positif pada return saham.

\section{SIMPULAN}

Berdasarkan hasil penelitian dapat disimpulkan bahwa intensitas pengungkapan dalam sustainability reporting tidak berpengaruh pada return saham. Pengungkapan informasi yang dilakukan perusahaan kurang maksimal atau kurang terbuka dan cenderung berfokus pada beberapa aspek pengungkapan sehingga pengungkapan yang dilakukan perusahaan merupakan upaya untuk memperoleh legitimasi bukan untuk perbaikan. Selain itu Investor dipasar modal indonesia belum sadar akan pentingnya mengelola perusahaan secara keberlanjutan. Demikian Intensitas pengungkapan yang tinggi belum tentu menarik minat investor untuk berinvestasi dan meningkatkan return saham perusahaan.

Bagi perusahaan disarankan untuk memberikan informasi tambahan mengenai kinerja keberlanjutannya tidak hanya sebatas informasi akhir sebagaimana diungkap pada sustainbility reporting namun lebih ke arah progresnya sehingga investor akan lebih yakin bahwa perusahaan telah dikelola dengan baik dan investor akan tertarik untuk berinvestasi, dengan demikian 
mendorong perusahaan tetap going concern. Bagi penelitian selanjutnya disarankan untuk menggunakan kombinasi variabel lainnya yang dapat mempengaruhi return saham yang tidak diteliti dalam penelitian ini dan memperpanjang periode pengujian agar dapat melihat kecenderungan yang terjadi dalam jangka waktu yang lebih panjang serta meningkatkan penggunaan jumlah sampel seperti penggunaan seluruh perusahaan yang terdaftar dibursa efek indonesia sehingga cakupan penelitian menjadi lebih besar.

\section{REFERENSI}

Acheampong, P., Agalega, E., \& Shibu, A.K. (2014). “The Effect of Financial Leverage And Market Size on Stock Returns on The Dhana Sector Exchange: Evidence From Selected Stock In The Manufacturing Sector." International Journal of Financial Research, 5(1), 125-134.

Adiatma, K. B. \& Suryanawa, I. K. (2018). "Pengaruh Tipe Industri, Kepemilikan Saham Pemerintah, Profitabilitas Terhadap Sustainability Report." eJurnal Akuntansi, 25(2): 934-958.

Al-Rojoub, S.A.M., Varela, O. \& Hassan, M.K. (2005). “The Size Effect Reversal in the USA." Journal of Applied Financial Economics, 15: 1189-1197.

Anggraini, Dewi. (2015). "Proven Again : Corporate Social Responsibility As One Of Influential Factors Towards Stock Return." European Journal of Business and Management 7(3):151-160.

Ansari, N., Cajias, M., \& Bienert, S. (2015). "The Value Contribution of Sustainability reportinging - An Empirical Evidence For Real Estate Companies." ACRN Oxford Journal of Finance and Risk Perspectives 4(4):190-205.

Antara, I. M. Y. \& Suryantini, N. P. S. (2019). "Pengaruh Rasio Pasar Terhadap Return Saham Pada Saham Lq-45 Di Bursa Efek Indonesia." E-Jurnal Manajemen 08(09):5507-5526.

Aji, B. S., \& Juliarto, A. (2018). “Pengaruh Pengungkapan Sustainability reporting Terhadap Reaksi Investor Pada Perusahaan Sektor Pertambangan Dan Manufaktur Yang Terdaftar Di Bei Periode 2014 - 2015." Diponegoro Journal Of Accounting 7(1):1-7.

Beaver, W. H., Kettler, P., \& Scholes, M. (1970). The Association betwen market determined and accounting fetermined risk measures. Accounting Review, (45), 654-668.

Brigham, E. F. \& J. F. Houston. (2011). Fundamentals of Financial Management. 9th ed. United States of America: Horcourt College.

Brundtland, G. H. (1987). Address at the Final Meeting of World Commission on Environment and Development (No. 0020t/W0006e/27.2.878/final/tokyo). Tokyo, Japan: World Commission on Environment and Development.

Candradewi, M. R. (2016). Pengaruh Kinerja Keuangan Terhadap Return Saham Pada Perusahaan Lq45 Di Bei: Analisis Regresi Data Panel. E-Jurnal Ekonomi Dan Bisnis Universitas Udayana, 5(7): 2091-2122.

Coulson, A. \& N. O'Sullivan. (2014). Environmental and Social Assessment in Finance. Pp. 124-40 in In Sustainability Accounting and Accountability, 
edited by J. Bebbington, J. Unerman, and B. O'Dwyer. New York: Routledge.

Deegan, Craig. (2004). Financial Accounting Theory. Australia: McGraw-Hill Australia Pty. Limited

Dimson, E., \& Marsh, P. (1999). Murphy's law and market anomalies. Journal of Portfolio Management, 25(2): 53-69.

Du, S., Y, K., Bhattacharya, C. B., \& Sen, S. (2017). The Business Case for Sustainability reportinging: Evidence from Stock Market Reactions. Journal of Public Policy and Marketing. 36 (2): 313-330.

Elkington, J. 1997. Cannibals With Forks, The Triple Bottom Line of 21stCentury Business. Oxford, UK: Capstone.

Epstein, Marc. J. \& Martin Freedman. (1994). Social Disclosure and The Individual Investor. Accounting, Auditing, \& Accountability Journal 4(7):94109.

Ernst \& Young. (2013). Value of Sustainability reportinging. USA: Boston College Carrol School of Management.

Glamedita, Lavenia. (2017). Hubungan Kinerja Keuangan dan Pengungkapan Sustainability reporting dengan Reaksi Pasar (Studi Empiris Pada Perusahaan Non-Keuangan di Bursa Efek Indonesia Tahun 2010-2014). (Skripsi). Yogyakarta: Universitas Sanata Dharma

Global Reporting Initiative. (2013). G4 Sustainability reportinging Guidelines. Amsterdam, The Netherlands: Global Reporting Initiative.

Handayani, M., Farlian, T., \& Ardian. (2019). Firm Size, Market Risk, and Stock Return: Evidence from Indonesian Blue Chip Companies. Jurnal Dinamika Akuntansi dan Bisnis, 6(2), 171-182.

Har, W. P. \& Ghafar, M.A.A. (2015). The Impact of Accounting Earnings on Stock Returns: The Case of Malaysia's Plantation Industry. International Journal of Business and Management, 10(4): 155-165.

Haq, I. U. \& Rashid, K. (2014). Stock Market Efficiency and Size of the Firm: Empirical Evidence from Pakistan. Oeconomics of Knowledge, 6(1): 10-31.

Husnan, S. \& Pudjiastuti, E. (2015). Dasar-dasar Manajemen Keuangan Edisi Keempat. Yogyakarta: UPP AMP-YKPN.

Indonesia Stock Exchange (IDX). (2020). Indeks Saham."Retrieved from (https://www.idx.co.id/produk/indeks/).

Ismaeel, M., \& Zakaria, Z. (2019). Perception of preparers of sustainability reports in the Middle East Contrasting between local and global. Meditari Accountancy Research, 28(1): 89-116.

Jogiyanto, H. (2017). Teori Portofolio Dan Analisis Investasi. 7th ed. Yogyakarta: BPFE.

Joni \& Lina. (2010). Faktor-Faktor yang Mempengaruhi Struktur Modal. Jurnal Bisnis dan Akuntansi, 12 (2): 81-96.

Karlina, S. \& Widanaputra. (2016). Pengaruh Dividend Per Share, Return On Equity, Price To Book Value Pada Return Saham." E-Jurnal Akuntansi Universitas Udayana 15(3):2082-2106.

Kholisah, N. (2013). Pengaruh Penerapan IFRS, Ukuran Perusahaan, Profitabilitas, dan Kompleksitas terhadap Audit Delay (Studi Empiris 
pada Perusahaan Manufaktur tahun 2008-2011). Skripsi. Jakarta: UIN Syarif Hidayatullah Jakarta

Mills, T. C., \& Jordanov, J. V. (2000). Lead-lag Patterns Between Small and Large Size Portfolios in the London Stock Exchange. Journal of Applied Financial Economics, 11(5): 489-495.

Natalia, R. \& J. Tarigan. (2014). Pengaruh Sustainability reporting Terhadap Kinerja Keuangan Perusahaan Publik Dari Sisi Profitability Ratio." Bussines Accounting Review 2(1):111-120.

Nawawi, A. H. T., Agustia, D., Lusnadi, G. M., \& Fauzi, H. (2020). Disclosure of Sustainability reporting Mediating Good Corporate Governance Mechanism on Stock Performance. Journal Of Security And Sustainability Issues. 9(J): 151-170.

Nelson, Mathew. (2017). How well are organizations disclosing their sustainability risks?." Retrieved from: https://www.ey.com/en_id/assurance/how-well-are-organizationsdisclosing-their-sustainability-risks

Norges Bank Investment Management. (2020). Shareholder Proposals On Sustainability (Asset Manager Perspective). Norges Bank Investment Management.

Nugroho, P. I. \& Arjowo, I. S. (2014). The Effects Of Sustainability reporting Disclosure Towards Financial Performance. International Journal of Business and Management Studies 03(03):225-239.

Papadopoulos, Kosmas. (2019). The Long View: The Role of Shareholder Proposals in Shaping US Corporate Governance (2000-2018). ISS Analytics.

POJK Nomor 51/POJK.03//2017 Tentang Penerapan Keuangan Berkelanjutan Bagi Lembaga Jasa Keuangan, Emiten, dan Perusahaan Publik

Prayosho, I. S., Hananto, H. (2013). Pengaruh Sustainability reporting Terhadap Abnormal Return Saham Pada Badan Usaha Sektor Pertambangan Yang Terdaftar Di BEI Periode 2010-2012. Calyptra:Jurnal Ilmiah Mahasiswa Universitas Surabaya 2(2):1-12.

Putra, I. M. G. D., \& Dana, I. M. (2016). Pengaruh Profitabilitas, Leverage, Likuiditas Dan Ukuran Perusahaan Terhadap Return Saham Perusahaan Farmasi Di Bei. E-Jurnal Manajemen Unud, 5(11), 6825-6850.

Reddy, K., \& Gordon, L. W. 2010. "The Effect of Sustainability reportinging on Financial Performance: An Empirical Study Using Listed Companies." Journal of Asia Entrepreneurship and Sustainability 6(2):19-42.

Rinaldi, L., J. Unerman, \& C. A. Tilt. (2014). The Role of Stakeholder Engagement and Dialogue in the Sustainability Accounting and Reporting Process." Pp. 86-107 in Sustainability Accounting and Accountability, edited by J. Bebbington, J. Unerman, and B. O’Dwyer. New York: Routledge.

Sailendra \& Suratno. (2014). Faktor-Faktor Fundamental, Kondisi Makro Ekonomi dan Return Saham Perusahaan Pertambangan di Bursa Efek Indonesia. Jurnal Riset Akuntansi dan Perpajakan JRAP, 1(1): 1-14.

Santi, Galuh Tiara. (2014). Pengaruh Pengungkapan Corporate Social Responsibility Terhadap Return Saham: Studi Pada Perusahaan Peraih Penghargaan Isra Di Bei Tahun 2010-2012. Pp. 1-22 in UDiNus Repository. 
Sasongko, N., \& Wulandari, N. (2006). Pengaruh EVA dan Rasio-Rasio Profitabilitas Terhadap Harga Saham. Jurnal Empirika, 19(1):64-80.

Scott, Mike. (2020). Investors Step Up Pressure On Companies That Don't Disclose Environmental Risks Forbes. Retrieved from: https://www.forbes.com/sites/mikescott/2020/06/09/investors-stepup-pressure-on-companies-that-dont-disclose-environmental risks $/$ ?sh $=3 \mathrm{e} 032445727 \mathrm{f}$

Stekelenburg, A. V., Georgakopoulos, G., Sotiropoulou, V., \& Vasileiou, K. Z. (2015). The Relation between Sustainability Performance and Stock Market Returns: An Empirical Analysis of the Dow Jones Sustainability Index Europe. International Journal of Economics and Finance, 7(7): 74-88.

Sudana, P., Sukoharsono, E. G., Ludigdo, U., \& Irianto, G. (2014). A Philosophical Thought on Sustainability Accounting. Research. Journal of Finance and Accounting, 5(9):1-10.

Sudarsono, B., Sudiyatno, B. (2016). Faktor-Faktor Yang Mempengaruhi Return Saham Pada Perusahaan Property Dan Real Estate Yang Terdaftar Pada Bursa Efek Indonesia Tahun 2009 S/D 2014. urnal Bisnis dan Ekonomi (JBE), 23(1):30-51.

Sudiyatno, B., \& Suharmanto, T. (2011). Kinerja Keuangan Konvensional, Economic Value Added, dan Return Saham. Jurnal Dinamika Manajemen, 2(1), 17-25.

Tang, D. Y., \& Zhong, R. (2019). Mandatory Sustainability Disclosure and Stock Price Crash Risk. http:/ / sfi.cuhk.edu.cn/uploads/paper/2019061208.pdf

Tanjung, P. R. S. \& Wahyudi, S. M. 2019. Analysis the Effect Disclosure of Sustainability reporting, Economic Value Added and Other Fundamental Factors of Companies on Company Value. International Journal of Academic Research in Accounting, Finance and Management Sciences 9(2):237-249.

Tarigan, J. \& Samuel, H. (2014). Pengungkapan Sustainability Report dan Kinerja Keuangan. Jurnal Akuntansi dan Keuangan, 16(2):88-101.

Tjahjono, M. E. S. (2017). Pengaruh Profitabilitas Terhadap Harga Saham (Studi Kasus Pada Perusahaan Makanan Dan Minuman Yang Terdaftar Di Bei Periode 2013-2015). Jurnal Riset Akuntansi Terpadu, 10(2): 152-165.

Utama, A. A. G. S., \& Mirhard, R. R. (2016). The influence of sustainability reporting disclosure as moderating variable towards the impact of intellectual capital on company's performance. International Journal of Economics and Financial Issues, 6(3): 1262-1269.

Vitola, F., \& Rubino, M. (2017). Legitimacy theory and sustainability reporting. Evidence from Italy. 10th Annual Conference of the EuroMed Academy of Business, 1908-1921.

Widhiarso, W. (2011). Analisis Data Penelitian dengan Variabel Kontrol. Jurnal Fakultas Psikologi Universitas Gadjah Mada, 3(2), 62-79.

Wijaya, M. S. \& Sudana, I. P. (2017). Pengaruh Sustainability reporting Pada Reaksi Pasar Dengan Kinerja Keuangan Sebagai Variabel Kontrol. E-Jurnal Akuntansi Universitas Udayana 21(1):616-642.

Wirasedana I. W. P., \& Setiawan, P. E. (2020). Rasio-Rasio Keuangan Sebagai Prediktor Return Saham Pada Perusahaan Manufaktur Yang Terdaftar Di Bursa Efek Indonesia. E-Jurnal Akuntansi, 30(6): 1508-1521. 
Yuliantari W., N., \& Sujana, I. (2014). Pengaruh Financial Ratio, Firm Size, Dan Cash Flow Operating Terhadap Return Share Perusahaan F\&B. E-Jurnal Akuntansi, 7(3), 547-558. 